\title{
SELECTED OPPORTUNITIES FOR ACCESS TO GERIATRIC CLIENTS FROM THE PERSPECTIVE OF ASSISTING PROFESSIONS
}

\author{
MICHAL VOSTRÝ \\ Faculty of Health studies, Jan Evangelista Purkyně University, \\ Velká Hradební 13, Ústí nad Labem, Czech Republic, \\ E-mail address: Michal.Vostry@ujep.cz
}

\begin{abstract}
Aim. The aim of the work was to find out the influence of ICT use (information and communication technology, in this case gaming console with motion sensor, which senses movements of the probands body and thus is controlled by a fictional figure in the game) on the rehabilitation of cognitive functions including attention and orientation.

Concept/methods. Alzheimer's disease is becoming increasingly the source of both professional and lay discourse. Statistical data show that increasing average life expectancy increases the number of seniors and thus increases the number of people with dementia, with Alzheimer's disease being the most common type (up to $65 \%$ of all cases of dementia in the Czech Republic). This trend will continue to follow, and the number of people affected will increase. For guidance in 2006, 2231 people with Alzheimer's disease were registered, while in 2010 this number increased to 3148 . For the research, 10 probands (100\% of women) were used in the age range of 65-81 years, with the diagnosis of Alzheimer's disease - a light type. Probands were divided into 5 groups, into an experimental group that actively participated in the intervention and services provided by the institutions in which they were located, and a control group that participated only in the services and activities provided by institution. The research lasted half a year once a week and the activity itself lasted within 25 minutes.

Results. Of the 10 probands in total, 5 participated actively in our intervention. Prior to the start of the intervention, the results in the assessment (using the Addenbrook Cognitive Assay) were at the same level, but there was visible change between the experimental and the control group during the outcomes assessment.

Conclusion. Experimental group achieved better scores or better results. The results themselves stagnated, while the control group experienced a minor deterioration in the test areas.

Key words: dementia, education, elderly education, occupational therapy, special education - intervention, comprehensive rehabilitation, motor deficiency.
\end{abstract}




\section{INTRODUCTION}

One of the main human cognitive functions is the human ability to learn and memorize. Such processes are always a certain result of psychosocial and biological factors. Human brain is a structure throughout which the biological sphere closely communicates with the psychological and social sphere. The brain development as a centre of unique cognitive, associative and memory functions determining the learning processes are largely complete even during prenatal development (Škoda, \& Doulík, 2001). Tiefenbacher (2010) characterizes memory as the brain ability to accept the intake information from environment. Such information is then, if necessary, stored and this way information is allowed to be recalled again ex post. The contemporary discussion of the issues tries to slow down the progression of the disease. Even early symptoms should be a warning and force is to choose a suitable activity for cognitive and motor function development (Bennett, 2008). Such individuals then seem less forgetful and are not as much disoriented, as others thus making the condition less severe, however even these slight symptoms should be examined in case of further development of Alzheimer's disease (Topinková, 2005). The more the condition progresses, the more the state of the patient worsens and the intervention itself is then, of course, more difficult (Bennett, Shand, \& Liddle, 2011). If we want to have the best results possible, it is necessary to start with the intervention as soon as possible, meaning from the point of first symptoms of early stages of dementia (Vostrý, \& Dončevová, 2016). Following the previous theme we can then add the knowledge to the education of senior members of the society, which is today done at universities of the Third Age (U3A). These institutions help develop their technological literacy etc. In many cases the elderly learn how to operate a computer and what are the pros and cons of using technology. A group of people with Alzheimer's is quite often being neglected, but it is the early stages of this condition which needs to be attended and help clients to be active and support their already disrupted cognitive functions. To have this, educative option can then be used as dementia prevention (Tomczyk, 2015). We can also mention one key study which pointed out the use of modern technology (in this particular case a game console and movement sensor) and video games to help people with disputed cognitive functions. One case study included a female senior (103 years), who was able to support her cognitive functions by the use of a bowling video game. The results and discussion of this study included a conclusion where author states that if cognitive functions are not stimulated enough, the overall health of clients and patients will inevitably deteriorate (Iorfino, 2013). To all of which Vostrý and Dončevová (2016) follow in their study. Their presented results of education intervention with the use of ICT revealed that experimental group showed signs of improvement after 6-month intervention. The output results in recommendations for professionals in general practice, engaging patients in regular activities with the employment of the ICT and similar technologies. 


\section{METHODS}

For the purpose of this particular research the causational research problem was contemplated (Gavora, 2010): What is the influence of the use of gaming consoles on the changes of cognitive function levels among people with dementia (light type of Alzheimer's disease). The goal is then to find out, whether the use of gaming consoles in ergotherapy intervention has any influence on the change of cognitive function levels. The testing itself was then done using a standardized test: "Questionnaire of changed seniors' abilities" which is widely used in occupational therapy for senior members of the society and thus was applied for input and outputs testing. The questionnaire of changed seniors' abilities is, according to the official text that appears on the diagnostic tool itself, designed to compare the current state with the past, in the case of changes, the answer is YES or NO. There are eight simple questions to which proband responds according to the answers mentioned. These are issues such as judgment problems, less interest in hobbies, forgetting data, repeating the same activities, and everyday problems with memory and thought. The results collected in the data sets from input and output testing were provided by a comparison between experimental and control group. The group of probands was divided into experimental (A - which actively participated in our intervention) and control ( $\mathrm{P}$ - which only used services provided by the institution where they lived) by a loss toss. For the intervention method we decided to use the console X-Box 360 with Kinect system and freeware commercial application Dr. Kawashima's body and brain. This gaming application is divided into various areas, all of which client is able to control with his/her body movement. ICT is then regarded as an addition to already existing standard ergotherapy (occupational therapy) procedures, which are usually done in a "paper and pencil" fashion. The research itself took approximately 6 months, once a week, each session around 25 mins. In case of this particular study we used a comparison of data with the use of nonparametric statistical method which doesn't require normal (Gauss) data distribution which was due to low number of individual's mere impossible. The statistical analysis contained the difference between input and output results. The difference values were then compared with each other by Mann-Whitney which calculated the effect size to be $\alpha=0,05$.

\section{RESULTS}

It can be seen from Table 1 that during the initial examination the probands from the experimental and control groups achieved similar results, while during the examination the experimental group improved point by three points in three probands, partly the results (in two probands) stagnated. The control group stagnated in most of the results, and four probands then worsened (by one point). This was primarily the questionnaire of forgetting data. It can be seen from Figure 1 that the experimental and control groups are at the same or similar point levels (pretest) at the entrance examination, whereas when comparing the results of 
the tests of the output (Graph 2) the evaluation is a statistically significant difference in favor of the experimental group, which achieves better results than the posttest. Figure 3 shows the arithmetic averages and confidence intervals of the overall results of the Elderly Change Questionnaire - Light Type.

Table 1. Questionnaire of changed seniors' abilities - difference between in and out testing.

\begin{tabular}{ccccc}
\hline \multicolumn{2}{c}{ Coming-in } & \multicolumn{2}{c}{ Coming-out } & in and out \\
\hline Group & $\begin{array}{c}\text { Number of } \\
\text { points }\end{array}$ & Group & $\begin{array}{c}\text { Number of } \\
\text { points }\end{array}$ & Difference \\
\hline E & 5 & E & 4 & 1 \\
E & 6 & E & 4 & 2 \\
E & 4 & E & 2 & 2 \\
E & 4 & E & 3 & 1 \\
E & 6 & E & 3 & 3 \\
E & 5 & E & 5 & 0 \\
E & 6 & E & 3 & 3 \\
E & 7 & E & 4 & 3 \\
E & 4 & E & 3 & 1 \\
E & 6 & E & 6 & 0 \\
C & 5 & C & 5 & 0 \\
C & 6 & C & 6 & 0 \\
C & 5 & C & 6 & -1 \\
C & 5 & C & 5 & 0 \\
C & 5 & C & 6 & -1 \\
C & 5 & C & 5 & 0 \\
C & 4 & C & 5 & -1 \\
C & 5 & C & 5 & 0 \\
C & 4 & C & 5 & -1 \\
C & 7 & C & 7 & 0 \\
\hline
\end{tabular}

Note: $\mathrm{E}=$ experimental group, $\mathrm{C}$ - controlling group. Source: Author's own work.

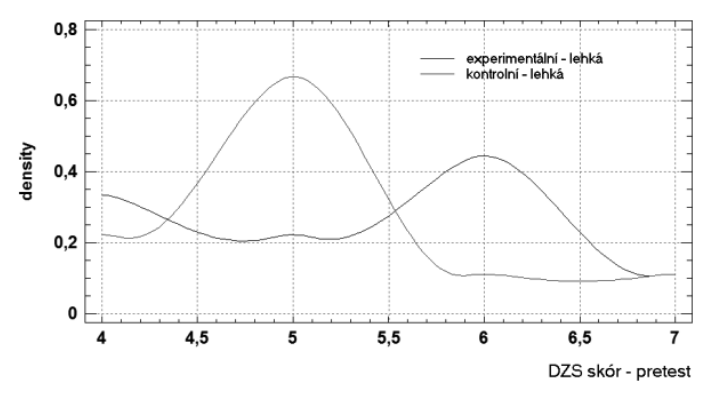

Figure 1. Distribution of difference between input and output testing - "Questionnaire of changed seniors' abilities" experimental group - pretest $(\mathrm{W}=62,5 \mathrm{P}$-value $=0,359974)$, (blue line $=$ experimental group, light type; red line = control group, light type). Source: Author's own work. 

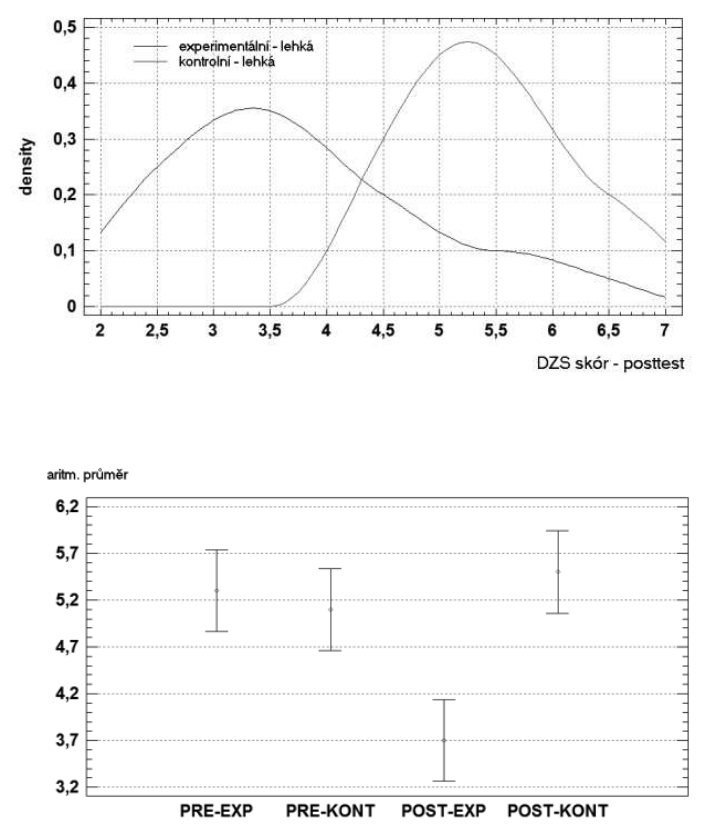

Figure 2. Distribution of difference between input and output testing - "Questionnaire of changed seniors' abilities" - experimental group - posttest $(\mathrm{W}=6.0 \mathrm{P}$-value $=0.000943149)$, (blue line $=$ experimental group, light type; red line $=$ control group, light type). Source: Author's own work.

Figure 3. Arithmetic averages and confidence intervals of the "Questionnaire of changed seniors' abilities" Overall Results (PRE-EXP = pretest experimental group; $\mathrm{PRE}-\mathrm{KONT}=$ pretest control group; POST-EXP = posttest experimental group; POST-KONT = posttest control group). Source: Author's own work.

\section{DISCUSSION}

Hátlová (2010) focused her work on psychomotor therapy for people suffering from dementia. Her approach includes exercise units, which are to stimulate an individual properly. The main idea of stimulation was also one of the goals in our study as well. In this particular intervention the stimulation included not only the movement apparatus, but also cognitive functions as well. Thanks to the body movement, probands we able to control a fictional character inside the video game connecting cognitive functions during which they also had to think about their move and use their memory, not to mention the cognitive training itself. Kolářová et al., (2012) in her article describes the work with elderly using the idea and observation of movement during cognitive and movement rehabilitation and states that the observation itself and imagination of movement has a positive influence on the optimal movement performance not only to be used for sportsmen, but also for people after trauma, or other neurological diagnosis. The resulted movement is then described by the individual quality of cognitive functions. These include: orientation in space (using visual and spatial area, which was a part of the rehabilitation process). The results of the study point to the fact, that the use of ICT has a positive effect on improving cognitive functions, based on the results of the experimental group. The essence is to maintain the seniors in both physical and mental condition. 
The use of ICT in therapy helps us to put these components together. Not only does the gaming seniors move, it also involves cognitive functions that are important to maintain even in the prevention of seniors who are not affected by a more serious illness.

\section{CONCLUSION}

There is not yet any accessible commercial product on the market which could fulfil the nature of cognitive function rehabilitation (Vostrý, \& Dončevová, 2016). The used product which was at our disposal can be evaluated as very useful. The tool fulfilled all criteria which were set at the beginning of the study. The only problem to which we have pointed to previously (articles, diploma thesis etc.), being the childish layout of the applications used and the set time limit, which then limits the full use of the application itself. It was the time which played a key role in completing all the tasks, which could not be done in time due to the limit set by the app. That is why only some parts of the app were used. The full potential then could not have been exploited e.g.: create and safe a file of game statistics even when the game goals were not fulfilled. The contemporary world is fully open to modern technologies and that is why a question needs to be raised: if in this area some products should be created. These products could help seniors and individuals suffering from dementia in increasing their life quality in general. Not only such individuals strive to become a part of the general populis (which creates the majority within a society), which uses technologies regularly and actively, but also they could further develop their cognitive skills (Hill, 2000). The study itself was quite complicated at first, when it comes to the negotiated time duration of the intervention, however over time organisational problems vanished completely. Probands (if we don't count in short term illnesses, exhaustion etc.) were with only little trouble participation and with little help were more than able to perform given tasks. As Laver et all., (2017) states in the management of the behavioural and psychological symptoms of dementia, and emphasize that symptoms should be prevented where possible and that, in the first place, non-pharmacological strategies should be used to manage the symptoms. One of the most effective interventions in the care of dementia is to provide staff with in-depth training on signs of dementia, personal care and the most effective communication with dementia and their carer's. Overall, the presented results point to the fact that by regular activation, clients can be slightly improved both cognitively and motorically. It is important to mention that a senior is going through a certain change in his life by moving himself from the home environment to which he is accustomed to facilities that provide social services. Here, to a certain extent, he may lose his privacy to which he was accustomed and, above all, loses contact with his social environment in which he lived all his life. This situation can become problematic and an integral part of the comprehensive rehabilitation is not only the client to rehabilitate therapeutically but 
also socially. Senior should be allowed access to a constant flow of information, which is nowadays very light access to modern technologies. Likewise, within the institution, it is important for the senior not to be situated in bed all the time, but to spend his free time in the society of other social service users and have the ability to move freely.

\section{REFERENCES}

1. Bennett, D., (2008). Alzheimer's, depression and dementia: a husband's observation. Longwood, FL: Xulon Press.

2. Bennett, S., Shand, S., \& Liddle, J. (2011). Occupational therapy practice in Australia with people with dementia: A profile in need of change. Australian Occupational Therapy Journal 58. 155-163.

3. Gavora, P. (2010). Úvod do pedagogického výzkumu [Introduction to pedagogical research]. Brno: Paido.

4. Hátlová, B., (2010). Psychomotorická terapie - Rehabilitace v klinické praxi [Psychomotor therapy - Rehabilitation in clinical practice]. Praha: Galén.

5. Hill, R. (2000). Cognitive rehabilitation in Old Age. Oxford: University Press.

6. Iorfino, M. (2013). Video games may help improve elderly's cognitive function. South Abington: Township.

7. Kolářová, B. at al., (2015). Využití představ a observace pohybu v kognitivní a pohybové rehabilitaci [Use of ideas and observation of movement in cognitive and physical rehabilitation]. Slovensko: Rehabilitácia.

8. Probst, M. (2010). Psychomotor Therapy and Psychiatry: What's in a Name? North America: Medicine Journal.

9. Škoda, J., \& Doulík, P. (2011) Psychodidaktika: metody efektivního a smysluplného učení a vyučování [Psychodidactics: methods of effective and meaningful learning and teaching]. Praha: Grada.

10. Tiefenbacher, A., (2010). Trénink paměti: osvědčené tipy, metody a cvičení [Memory training: proven tips, methods and exercises]. Praha: Grada.

11. Tomczyk, Ł., (2015). Vzdělávání seniorů v oblasti nových médií [Seniors training in new media]. Praha: Asociace institucí vzdělávání dospělých ČR.

12. Topinková, E. (2005). Geriatrie pro praxi [Geriatrics for practice]. Praga: Galén.

13. Vostrý, M., (2016). Efektivita edukačních intervencí u Alzheimerovy choroby [Effectiveness of educational interventions in Alzheimer's disease]. Ústí nad Labem: Univerzita J. E. Purkyně v Ústí nad Labem, Pedagogická fakulta.

14. Vostrý, M., \& L. Dončevová, L. (2016). Trénování paměti v ergoterapii pomocí herní konzole u lehkého typu demence [Training your memory in ergotherapy using a gaming console for light type dementia]. Sociálno-zdravotnícké spectrum, 15,1-7. 